\title{
PEMODELAN SISTEM FUZZY DENGAN MENGGUNAKAN MATLAB
}

\author{
Afan Galih Salman \\ Jurusan Teknik Informatika, Fakultas Ilmu Komputer, Bina Nusantara University \\ Jln. K.H. Syahdan No 9, Palmerah, Jakarta Barat 11480 \\ asalman@binus.edu
}

\begin{abstract}
Fuzzy logic is a method in soft computing category, a method that could process uncertain, inaccurate, and less cost implemented data. Some methods in soft computing category besides fuzzy logic are artificial network nerve, probabilistic reasoning, and evolutionary computing. Fuzzy logic has the ability to develop fuzzy system that is intelligent system in uncertain environment. Some stages in fuzzy system formation process is input and output analysis, determining input and output variable, defining each fuzzy set member function, determining rules based on experience or knowledge of an expert in his field, and implementing fuzzy system. Overall, fuzzy logic uses simple mathematical concept, understandable, detectable uncertain and accurate data. Fuzzy system could create and apply expert experiences directly without exercise process and effort to decode the knowledge into a computer until becoming a modeling system that could be relied on decision making.
\end{abstract}

Keywords: fuzzy logic, soft computing, fuzzy system, decision making.

\begin{abstract}
ABSTRAK
Logika Fuzzy adalah metode yang termasuk dalam kategori Softcomputing, metode yang dapat mengolah data-data yang bersifat tidak pasti, impresisi dan dapat diimplementasikan dengan biaya yang murah. Beberapa metode yang termasuk dalam kategori softcomputing selain logika fuzzy adalah jaringan saraf tiruan, probabilistic reasoning dan evolutionary computing. Logika fuzzy mempunyai kemampuan untuk mengembangkan sistem fuzzy yaitu sistem intelijen dalam lingkungan yang tak pasti. Beberapa tahapan proses pembentukan sistem fuzzy yaitu analisa input maupun output, penentuan variabel input dan output, penentuan fungsi keanggotaan masing-masing himpunan fuzzynya, penetapan aturan-aturan berdasarkan pengalaman atau pengetahuan seorang pakar di bidangnya dan implementasi sistem fuzzy. Secara keseluruhan logika fuzzy menggunakan konsep matematis sangat sederhana, mudah dimengerti dan memiliki toleransi terhadap datadata yang tidak tepat atau kabur. Sistem fuzzy dapat membangun dan mengaplikasikan pengalaman-pengalaman para pakar secara langsung tanpa harus melalui proses latihan dan berusaha menerjemahkan pengetahuan yang dimiliki sang ahli ke dalam sistem komputer hingga menjadi suatu sistem pemodelan yang benar-benar bisa diandalkan dalam pengambilan keputusan.
\end{abstract}

Kata kunci: logika fuzzy, softcomputing, sistem fuzzy, pengambilan keputusan. 


\section{PENDAHULUAN}

Soft Computing merupakan inovasi baru dalam membangun sistem cerdas. Sistem cerdas ini merupakan sistem yang memiliki keahlian seperti manusia pada domain tertentu, mampu beradaptasi dan belajar agar dapat bekerja lebih baik jika terjadi perubahan lingkungan. Unsur-unsur pokok dalam Soft Computing adalah sistem fuzzy, jaringan saraf tiruan, probabilistic reasoning, evolutionary computing.

Sistem fuzzy secara umum terdapat 5 langkah dalam melakukan penalaran, yaitu memasukkan input fuzzy, mengaplikasikan operator fuzy, mengaplikasikan metode implikasi, komposisi semua output, dan defuzifikasi. Dalam hal ini, penulis mencoba menganalisis dan menerjemahkan pengetahuan seorang pakar pemasaran dan produksi yang telah bertahun-tahun melakukan penelitian hingga menemukan suatu teknik proses penentuan jumlah minimum produksi dan permintaan pasar dengan pendekatan sistem fuzzy.

Tujuan penelitian ini adalah untuk memprediksi atau memperkirakan jumlah produksi minimum suatu produk berdasarkan aturan-aturan yang telah ditetapkan oleh ahlinya atau berdasarkan pengalaman ahlinya selama melakukan penelitian. Untuk tujuan ini diambil studi kasus tentang permasalahan jumlah produksi minimum permen coklat terhadap biaya produksi dan permintaan pasar. Membuat model sistem fuzzy yang benar-benar bisa diandalkan dalam pengambilan keputusan dengan menaplikasikan pengalaman-pengalaman para pakar secara langsung tanpa harus melalui proses latihan dan berusaha menerjemahkan pengetahuan yang dimiliki sang ahli ke dalam sistem komputer hingga menjadi suatu sistem pemodelan.

Lingkup permasalahan hanya terbatas pada studi kasus dalam rangka menentukan jumlah produksi minimum permen coklat terhadap biaya produksi dan permintaan pasar. Penentuan ini didasarkan pada sejumlah kriteria yang telah ditetapkan oleh ahlinya. Masalah ini terlebih dahulu akan dianalisis dengan pendekatan sistem fuzzy untuk mendapatkan variabel-variabel yang akan dijadikan dasar pembuatan model fuzzy. Selanjutnya ditentukan himpunan-himpunan keanggotaan fuzzy yang terkait dengan variabel yang telah ditetapkan sebelumnya. Apabila tahap-tahap analisis tersebut berjalan dengan baik, maka pemodelan sistem fuzzynya akan diimplementasikan dengan menggunakan toolbox MATLAB ver 7.0. Implementasi sistem fuzzy ini diharapkan mampu memberikan solusi terhadap permasalahan studi kasus penentuan jumlah produksi minimum permen coklat terhadap biaya produksi dan permintaan pasar.

Logika Fuzzy adalah suatu cara yang tepat untuk memetakan suatu ruang input ke dalam ruang output. Untuk sistem yang sangat rumit, penggunaan logika fuzzy (fuzzy logic) adalah salah satu pemecahannya. Sistem tradisional dirancang untuk mengontrol keluaran tunggal yang berasal dari beberapa masukan yang tidak saling berhubungan. Karena ketidaktergantungan ini, penambahan masukan yang baru akan memperumit proses kontrol dan membutuhkan proses perhitungan kembali dari semua fungsi . Kebalikannya, penambahan masukan baru pada sistem fuzzy, yaitu sistem yang bekerja berdasarkan prinsip-prinsip logika fuzzy, hanya membutuhkan penambahan fungsi keanggotaan yang baru dan aturan-aturan yang berhubungan dengannya.

Secara umum, sistem fuzzy sangat cocok untuk penalaran pendekatan terutama untuk sistem yang menangani masalah-masalah yang sulit didefinisikan dengan menggunakan model matematis Misalkan, nilai masukan dan parameter sebuah sistem bersifat kurang akurat atau kurang jelas, sehingga sulit mendefinisikan model matematikanya. Sistem fuzzy mempunyai beberapa keuntungan bila dibandingkan dengan sistem tradisional, misalkan pada jumlah aturan yang dipergunakan. Pemrosesan awal sejumlah besar nilai menjadi sebuah nilai derajat keanggotaan pada sistem fuzzy mengurangi jumlah nilai menjadi sebuah nilai derajat keanggotaan pada sistem fuzzy mengurangi 
jumlah nilai yang harus dipergunakan pengontrol untuk membuat suatu keputusan. Keuntungan lainnya adalah sistem fuzzy mempunyai kemampuan penalaran yang mirip dengan kemampuan penalaran manusia. Hal ini disebabkan karena sistem fuzzy mempunyai kemampuan untuk memberikan respon berdasarkan informasi yang bersifat kualitatif, tidak akurat, dan ambigu.

Menurut Kusumadwi (2002), beberapa alasan penggunaan logika fuzzy adalah (1) logika fuzzy sangat fleksibel; (2) logika fuzzy memiliki toleransi; (3) konsep matematis yang mendasari penalaran fuzzy sangat sederhana dan mudah dimengerti; (4) logika fuzzy mampu memodelkan fungsi-fungsi nonlinear yang sangat kompleks; (5) logika fuzzy dapat membangun dan mengaplikasikan pengalaman-pengalaman para pakar secara langsung tanpa harus melalui proses pelatihan; (6) logika fuzzy dapat bekerjasama dengan teknik-teknik kendali secara konvensional; dan (7) logika fuzzy didasarkan pada bahasa alami.

Sistem fuzzy pertama kali diperkenalkan oleh Prof. L. A. Zadeh dari Barkelay pada tahun 1965. Sistem fuzzy merupakan penduga numerik yang terstruktur dan dinamis. Sistem ini mempunyai kemampuan untuk mengembangkan sistem intelijen dalam lingkungan yang tak pasti. Sistem ini menduga suatu fungsi dengan logika fuzzy. Dalam logika fuzzy terdapat beberapa proses yaitu penentuan himpunan fuzzy, penerapan aturan IF-THEN dan proses inferensi fuzzy (Marimin, 2005).

Ada beberapa hal yang perlu diketahui dalam memahami sistem fuzzy yaitu variabel fuzzy, himpunan fuzzy, semesta pembicaraan dan domain (Kusumadewi \& Purnomo, 2004). Variabel Fuzzy merupakan variabel yang akan dibahas dalam sistem fuzzy misalnya umur, temperatur, permintaan, dsb. Himpunan Fuzzy merupakan suatu group yang mewakili suatu kondisi tertentu dalam variabel fuzzy misalnya variabel umur dibagi atas 3 himpunan fuzzy yaitu muda, parobaya dan tua. Semesta Pembicaraan adalah keseluruhan nilai yang diperbolehkan untuk dioperasikan dalam suatu variabel fuzzy misalnya semesta pembicaraan variabel umur adalah 0 sampai 100. Domain adalah keseluruhan nilai yang diijinkan dalam semesta pembicaraan dan boleh dioperasikan dalam himpunan fuzzy misalnya domain umur muda 20 - 45, domain parobaya $25-65$ dan domain tua $45-70$.

Pada himpunan biasa (crisp) nilai keanggotaan memiliki 2 kemungkinan yaitu satu (1) berarti menjadi anggota himpunan dan dua (2) berarti tidak menjadi anggota. Bila 20-<35 himpunan umur muda, 35-<55 himpunan parobaya, maka seseorang berumur 35 tahun masuk himpunan parobaya, sedang umur 35 tahun kurang 1 hari masuk himpunan muda. Meskipun selisih umur hanya 1 hari, namun mengakibatkan perbedaan kategori cukup bermakna (Gambar 1).

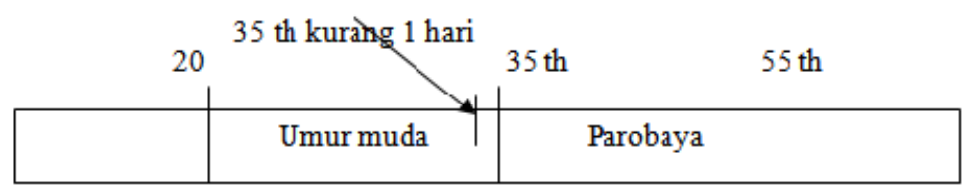

Gambar 1 Keanggotaan himpunan biasa umur muda dan parobaya.

Dalam himpunan fuzzy seseorang dapat masuk dalam 2 himpunan yang berbeda. Seseorang berumur 40 tahun masuk himpunan berumur muda dengan derajat keanggotaan 0,15 dan sekaligus masuk himpunan berumur parobaya dengan derajat keanggotaan 0,85 (Gambar 2).

Fungsi keanggotaan adalah kurva yang menunjukkan pemetaan titik input data ke dalam nilai keanggotaan yang mempunyai interval $0-1$. Ada beberapa fungsi keanggotaan yang digunakan antara lain representasi kurva sigmoid, trapesoid dan triangular. Seperti himpunan biasa, ada beberapa operasi yang didefinisikan secara khusus untuk mengkombinasikan himpunan fuzzy. Ada 3 operator dasar yang diciptakan Zadeh yaitu operator $A N D$, OR dan NOT. Nilai keanggotaan baru sebagai hasil dari operasi 2 himpunan disebut $\alpha$-predikat. 


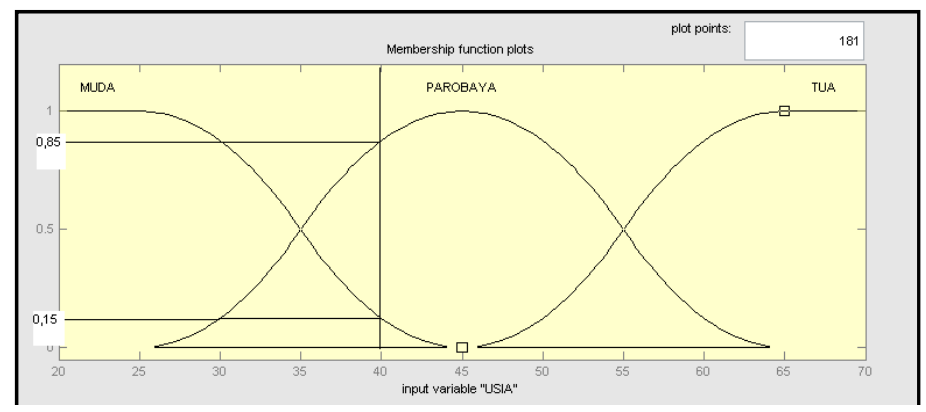

Gambar 2 Fungsi keanggotaan "USIA" dengan representasi sigmoid.

Operator AND merupakan operasi interseksi pada himpunan. $\alpha$-predikat yang dihasilkan diperoleh dengan mengambil nilai keanggotaan terkecil antar elemen pada himpunan bersangkutan. Misal nilai keanggotaan umur 27 pada himpunan muda adalah $\mu \operatorname{MUDA}[27]=0,6$ dan nilai keanggotaan 2 juta pada himpunan penghasilan TINGGI adalah $\mu$ GAJITINGGI[2juta] $=0,8$ maka $\alpha$-predikat untuk usia MUDA dan berpenghasilan TINGGI adalah nilai keanggotaan minimum:

$$
\begin{aligned}
\mu \mathrm{MUDA} \cap \mathrm{GAJITINGGI} & =\min (\mu \mathrm{MUDA}[27], \mu \text { GAJITINGGI[2juta] }) \\
& =\min (0,6 ; 0,8) \\
& =0,6
\end{aligned}
$$

Operator OR merupakan operasi union pada himpunan. $\alpha$-predikat yang dihasilkan diperoleh dengan mengambil nilai keanggotaan terbesar antar elemen pada himpunan bersangkutan. Misal nilai keanggotaan umur 27 pada himpunan muda adalah $\mu$ MUDA[27] $=0,6$ dan nilai keanggotaan 2 juta pada himpunan penghasilan TINGGI adalah $\mu$ GAJITINGGI[2juta] $=0,8$ maka $\alpha$-predikat untuk usia MUDA atau berpenghasilan TINGGI adalah nilai keanggotaan maksimum :

$$
\begin{aligned}
\mu_{\text {MUDA } \cap \text { GAJITINGGI }} & =\max \left(\mu_{\text {MUDA[27], }} \mu_{\text {GAJITINGGI[2juta] })}\right. \\
& =\max (0,6 ; 0,8) \\
& =0,8
\end{aligned}
$$

Operator NOT merupakan operasi komplemen pada himpunan. $\alpha$-predikat yang dihasilkan diperoleh dengan mengurangkan nilai keanggotaan elemen pada himpunan dari 1 . Misal nilai keanggotaan umur 27 pada himpunan muda adalah $\mu \mathrm{MUDA}[27]=0,6$ maka $\alpha$-predikat untuk usia TIDAK MUDA adalah :

$$
\begin{aligned}
\mu \text { MUDA' }^{\prime}[27] & =1-\mu \operatorname{MUDA}[27 \\
& =1-0,6 \\
& =0,4
\end{aligned}
$$

Tiap aturan (proposisi) pada basis pengetahuan fuzzy akan berhubungan dengan suatu relasi fuzzy. Bentuk umum aturan yang digunakan dalam fungsi implikasi adalah:

$$
\text { IF } \mathrm{x} \text { is } \mathrm{A} \text { THEN } \mathrm{y} \text { is } \mathrm{B}
$$

$\mathrm{x}$ dan y adalah skalar sedang A dan B adalah himpunan fuzzy. Proposisi yang mengikuti IF disebut anteseden, sedangkan proposisi yang mengikuti THEN disebut konsekuen. Secara umum ada 2 fungsi 
implikasi yaitu fungsi implikasi Min (minimum) dan fungsi implikasi DOT (product). Misal bentuk aturan sebagai berikut:

\section{[R1] IF Permintaan NAIK AND Stok SEDIKIT THEN Produksi TINGGI}

Nilai keanggotaan Permintaan 8.000 pada himpunan Permintaan NAIK adalah $\mu$ NAIK[8.000] $=0,7$ dan nilai keanggotaan Stok 10.000 pada himpunan Stok SEDIKIT adalah $\mu$ SEDIKIT[10.000]=0,9 maka fungsi implikasi untuk Produksi TINGGI adalah perpotongan nilai keanggotaan minimum sehingga nilai keanggotaan Produksi TINGGI adalah $\mu$ TINGGI $=0,7$.

Aplikasi Fungsi implikasi Min (minimum) memotong output sebagai berikut:

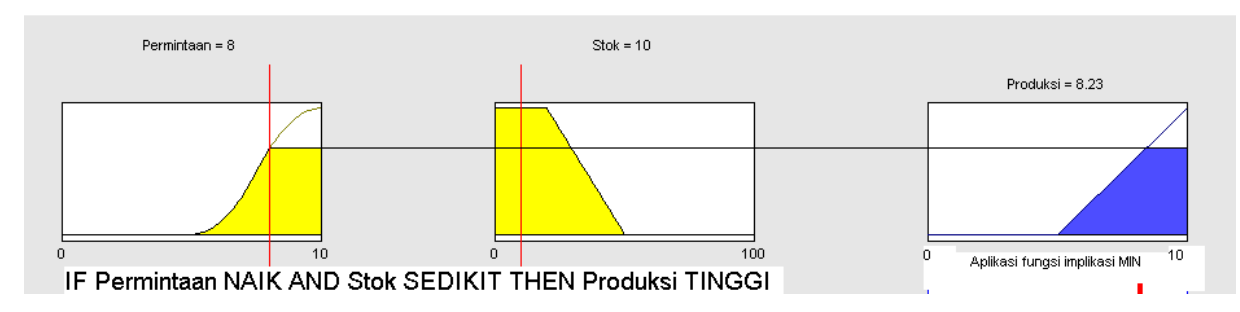

Gambar 3 Fungsi implikasi MIN

Aplikasi Fungsi implikasi DOT (product) akan menskala output sebagai berikut:

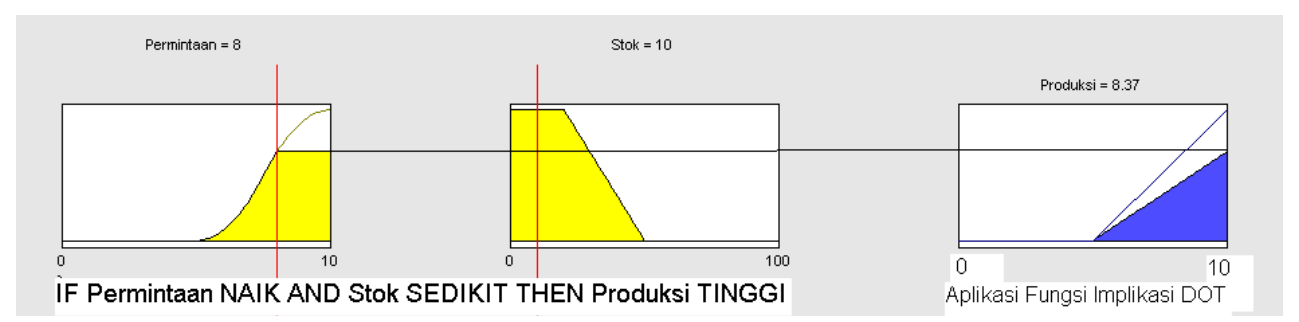

Gambar 4 Fungsi implikasi DOT

Ada beberapa metode untuk merepresentasikan hasil logika fuzzy yaitu metode Tsukamoto, Sugeno dan Mamdani. Pada metode Tsukamoto, setiap konsekuen direpresentasikan dengan himpunan fuzzy dengan fungsi keanggotaan monoton. Output hasil inferensi masing-masing aturan adalah $z$, berupa himpunan biasa (crisp) yang ditetapkan berdasarkan $\alpha$-predikatnya. Hasil akhir diperoleh dengan menggunakan rata-rata terbobotnya. ( Kusumadewi, 2002)

Metode Sugeno mirip dengan metode Mamdani, hanya output (konsekuen) tidak berupa himpunan fuzzy, melainkan berupa konstanta atau persamaan liniar. Ada dua model metode Sugeno yaitu model fuzzy sugeno orde nol dan model fuzzy sugeno orde satu. Bentuk umum model fuzzy sugeno orde nol adalah:

IF ( $x 1$ is $A 1)$ o $(x 2$ is $A 2)$ o … o ( $x n$ is An) THEN $z=k$

Bentuk umum model fuzzy Sugeno orde satu adalah:

IF ( $x 1$ is $A 1)$ o ( $x 2$ is A2) o .... o ( $x n$ is An) THEN $z=p 1 . x 1+\ldots$ pn.xn $+q$ Defuzzifikasi pada metode Sugeno dilakukan dengan mencari nilai rata-ratanya. 


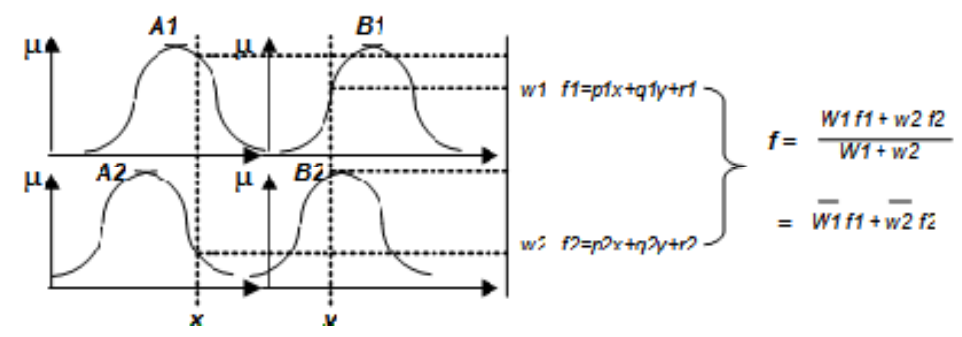

Gambar 5 Model fuzzy sugeno orde 1

Pada metode Mamdani, aplikasi fungsi implikasi menggunakan $M I N$, sedang komposisi aturan menggunakan metode $M A X$. Metode Mamdani dikenal juga dengan metode $M A X-M I N$. Inferensi output yang dihasilkan berupa bilangan fuzzy maka harus ditentukan suatu nilai crisp tertentu sebagai output. Proses ini dikenal dengan defuzzifikasi. Ada beberapa tahapan untuk mendapatkan output yaitu (1) pembentukan himpunan fuzzy, pada metode Mamdani baik variabel input maupun variabel output dibagai menjadi satu atau lebih himpunan fuzzy; (2) aplikasi fungsi implikasi, pada metode Mamdani, fungsi implikasi yang digunakan adalah Min; (3) komposisi aturan, tidak seperti penalaran monoton, apabila sistem terdiri dari beberapa aturan, maka inferensi diperoleh dari kumpulan dan korelasi antar aturan. Ada 3 metode yang digunakan dalam melakukan inferensi sistem fuzzy yaitu Max, Additive dan Probabilistik OR.

\section{Metode Max (Maximum)}

Pada metode ini solusi himpunan fuzzy diperoleh dengan cara mengambil nilai maksimum aturan, kemudian menggunakannya untuk memodifikasi daerah fuzzy dan mengaplikasikan ke output dengan menggunakan operator OR(union). Jika semua proposisi telah dievaluasi, maka output akan beisi suatu himpunan fuzzy yang merefleksikan konstribusi dari tiap-tiap proposisi. Secara umum dapat dituliskan:

$$
\begin{aligned}
& \mu \mathrm{sf}[\mathrm{xi}] \leftarrow \max (\mu \mathrm{sf}[\mathrm{xi}], \mu \mathrm{kf}[\mathrm{xi}]) \\
& \text { dengan : } \\
& \mu \mathrm{sf}[\mathrm{xi}]=\text { nilai keanggotaan solusi fuzzy sampai aturan ke-i } \\
& \mu \mathrm{kf}[\mathrm{xi}]=\text { nilai keanggotaan konsekuen fuzzy aturan ke-i }
\end{aligned}
$$

\section{Metode Additive (Sum)}

Pada metode ini, solusi himpunan fuzzy diperoleh dengan cara melakukan bounded-sum terhadap semua output dareah fuzzy. Secara umum dituliskan:

$$
\begin{aligned}
& \mu \mathrm{sf}[\mathrm{xi}] \leftarrow \max (1, \mu \mathrm{sf}[\mathrm{xi}]+\mu \mathrm{kf}[\mathrm{xi}]) \\
& \mu \mathrm{sf}[\mathrm{xi}]=\text { nilai keanggotaan solusi fuzzy sampai aturan ke-i } \\
& \mu \mathrm{kf}[\mathrm{xi}]=\text { nilai keanggotaan konsekuen fuzzy aturan ke-i }
\end{aligned}
$$

\section{Metode Probabilistik OR}

Pada metode ini, solusi himpunan fuzzy diperoleh dengan cara melakukan product terhadap semua output daerah fuzzy. Secara umun dituliskan: $\mu \mathrm{sf}[\mathrm{xi}] \leftarrow \max (\mu \mathrm{sf}[\mathrm{xi}]+\mu \mathrm{kf}[\mathrm{xi}])-(\mu \mathrm{sf}[\mathrm{xi}] * \mu \mathrm{kf}[\mathrm{xi}])$ $\mu \mathrm{sf}[\mathrm{xi}]=$ nilai keanggotaan solusi fuzzy sampai aturan ke-i $\mu \mathrm{kf}[\mathrm{xi}]=$ nilai keanggotaan konsekuen fuzzy aturan ke-i 


\section{Penegasan /Defuzzifikasi}

Input dari proses Defuzzifikasi adalah suatu himpunan fuzzy yang diperoleh dari komposisi aturan-aturan fuzzy, sedangkan output yang dihasilkan merupakan suatu bilangan pada domain himpunan fuzzy tersebut. Sehingga jika diberikan suatu himpunan fuzzy dalam range tertentu, maka harus dapat diambil suatu nilai crisp tertentu sebagai output. Ada beberapa metoda yang dipakai dalam defuzzifikasi adalah (1) Metode Centroid, penetapan nilai crisp dengan cara mengambil titik pusat daerah fuzzy; (2) Metode Bisektor, solusi crisp diperoleh dengan cara mengambil nilai pada domain fuzzy yang memiliki nilai keanggotaan seperti dari jumlah total nilai keanggotaan pada daerah fuzzy; (3) Metode Means of Maximum (MOM), diperoleh dengan cara mengambil nilai rata-rata domain yang memiliki niali keanggotaan maksimum; (4) Metode Largest of Maximum (LOM), diperoleh dengan cara mengambil nilai terbesar dari domain yang memiliki niali keanggotaan maksimum; (5) Metode Smallest of Maksimum (SOM), diperoleh dengan cara mengambil niali terkecil dari domain yang memiliki nilai keanggotaan maksimum.

\section{METODE}

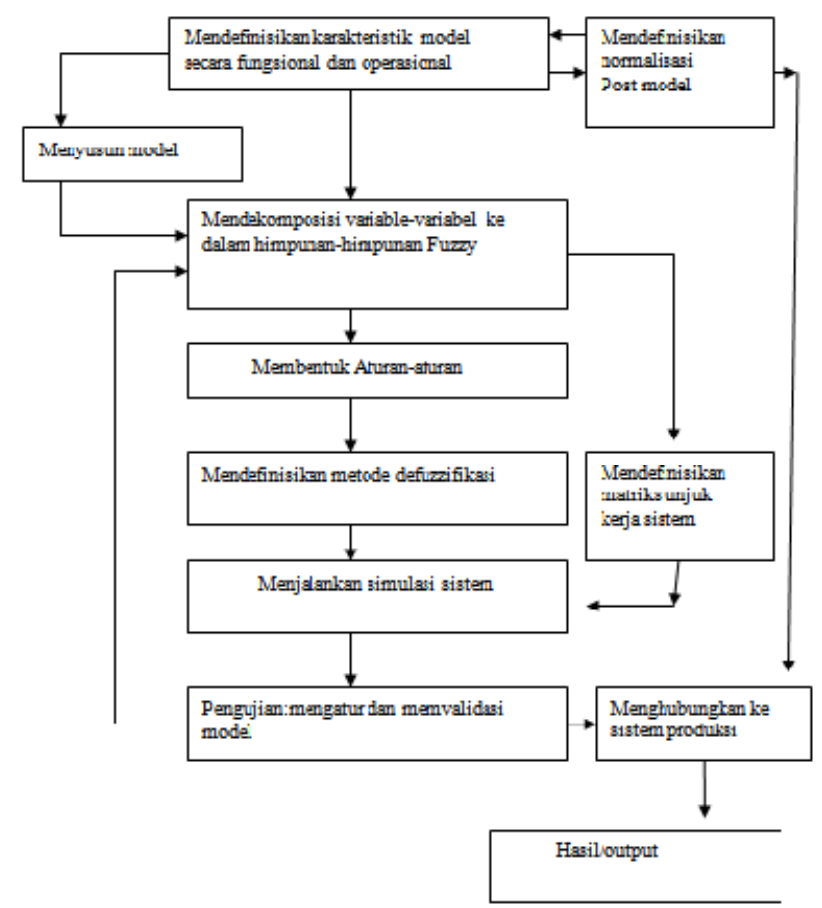

\section{Bahan dan Alat}

Gambar 6 langkah-langkah pengembangan sistem fuzzy

Bahan dan alat yang digunakan adalah perangkat keras berupa Personal Computer (PC) minimal pentium IV serta perangkat lunak berupa MATLAB versi 7.

\section{Prosedur Percobaan dan Kajian}

Langkah awal pembuatan sistem fuzzy pada MATLAB versi 7.0 adalah menentukan variabel input yang terdiri dari variabel biaya produksi dan variabel permintaan dan menentukan variabel output yaitu variabel produksi barang. 


\section{Data Masukan (Input)}

Data yang diambil dari studi kasus sebuah perusahaan permen coklat di Bogor. Suatu perusahaan permen coklat akan memproduksi permen coklat jenis X. Pada 3 bulan terakhir biaya produksi untuk permen coklat jenis tersebut rata-rata sekitar Rp. 500,- per kemasan, dan maksimum mencapai Rp. 1000,- perkemasan. Banyaknya permintaan per hari rata-rata mencapai 30000 kemasan dan maksimum hingga mencapai 60000 kemasan. Sampai saat ini, perusahaan baru mampu produksi barang maksimum 100000 kemasan perhari. Apabila proses produksi perusahaan tersebut menggunakan 3 aturan fuzzy sebagai berikut: [R1] If Biaya Produksi RENDAH and Permintaan NAIK THEN Produksi Barang BERTAMBAH; [R1] If Biaya Produksi Sesuai STANDAR THEN Produksi Barang NORMAL; [R1] If Biaya Produksi TINGGI and Permintaan TURUN THEN Produksi Barang BERKURANG.

Langkah berikutnya yaitu menentukan kriteria proses pembuatan sistem fuzzy, yaitu Metoda = Mamdani, And Method $=$ Min, Or Method $=$ Max, Implikasi $=$ Min, Aggregasi $=$ Max, dan Defuzifikasi $=$ Centroid

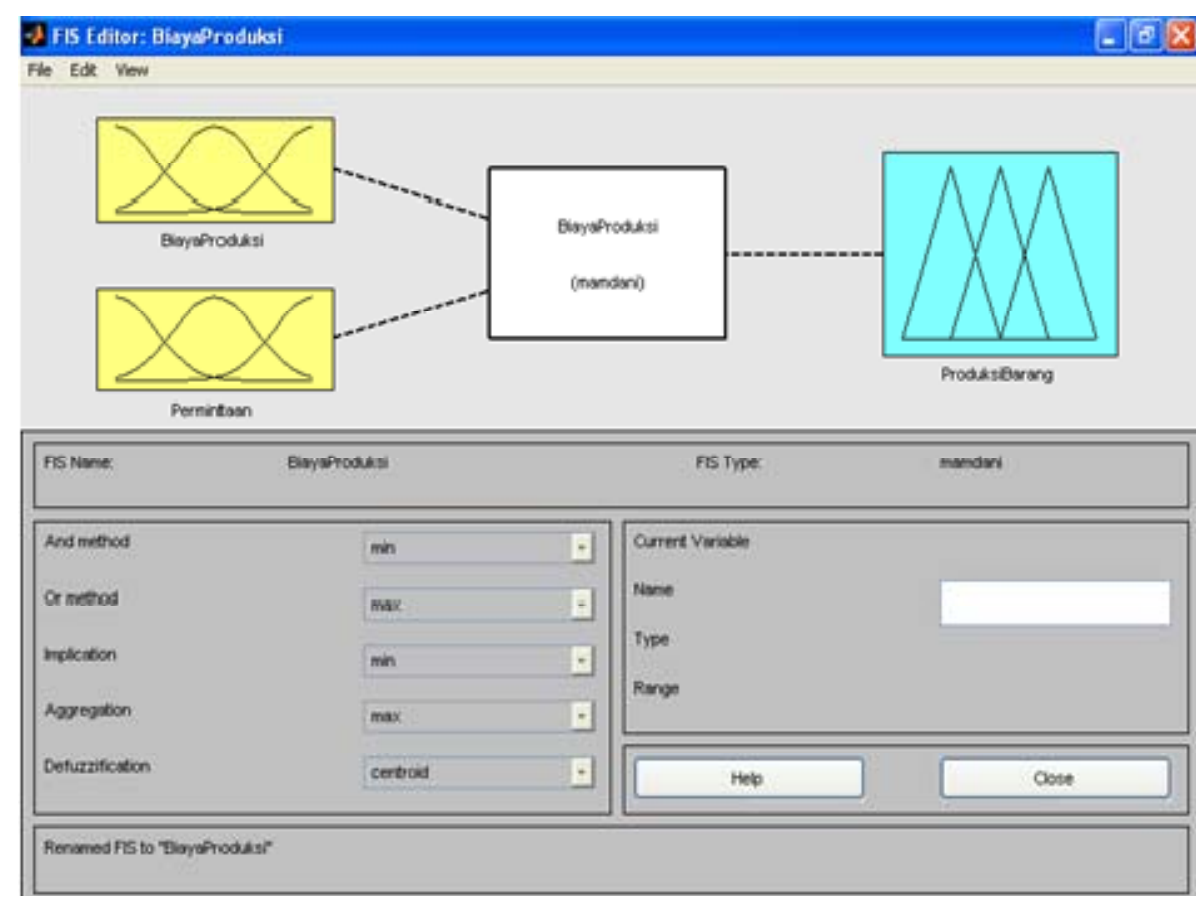

Gambar 7 Penentuan kriteria sistem Fuzzy

\section{Variabel Biaya Produksi}

Untuk mempresentasikan variabel Biaya Produksi digunakan kurva berbentuk S (untuk himpunan fuzzy RENDAH \& TINGGI) dan kurva bentuk $\pi$ (untuk himpunan fuzzy STANDAR) Gambar 8 .

Fungsi Keanggotan Biaya Produksi:

$$
\mu_{\text {BP Rendah }} \quad(x)= \begin{cases}1-2(\mathrm{x} / 500)^{2} ; & \mathrm{x} \leq 250 \\ (500-\mathrm{x}) / 500)^{2} ; & 250 \leq \mathrm{x} \leq 500 \\ 0 ; & \mathrm{x} \geq 500\end{cases}
$$




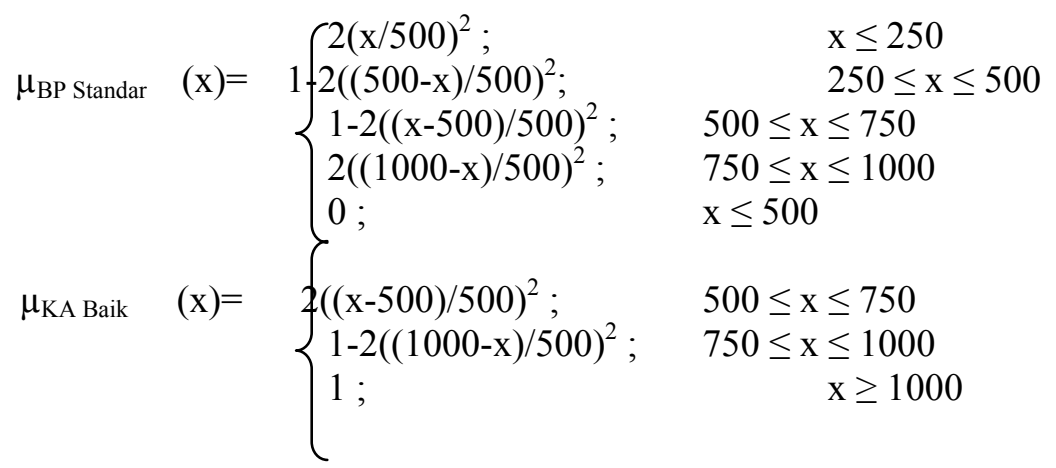

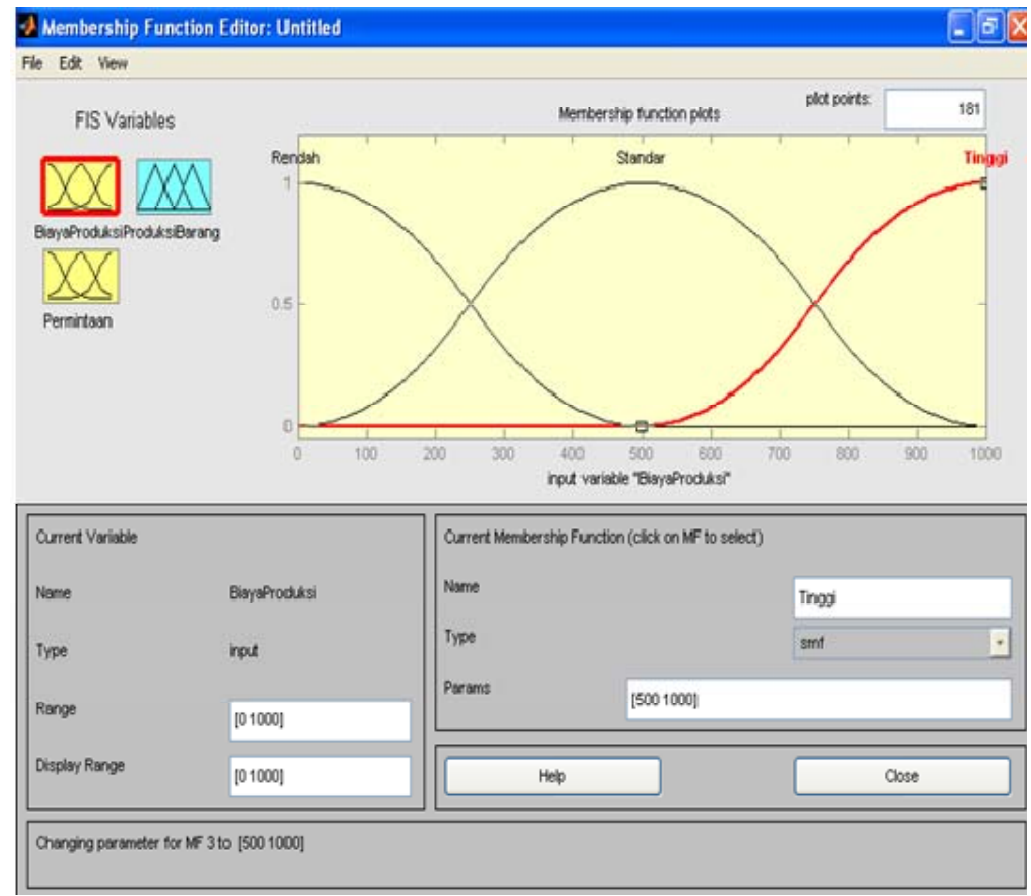

Gambar 8 Membership Function

\section{Variabel Permintaan}

Untuk mempresentasikan variabel Permintaan digunakan kurva berbentuk bahu (untuk fuzzy TURUN \& NAIK) dan kurva bentuk segitiga (untuk himpunan fuzzy BIASA) seperti Gambar 9 di bawah ini:

\section{Skala : Permintaan ( 1000 kemasan perhari )}

Fungsi Keanggota Permintaan :

$$
\begin{aligned}
& \mu_{\text {Pmt Turun }}(\mathrm{y})=\left(\begin{array}{ll}
1 ; & \mathrm{y} \leq 10 \\
0-\mathrm{y})) / 20 ; & 10 \leq \mathrm{y} \leq 30 \\
0 ; & \mathrm{y} \geq 30
\end{array}\right. \\
& \mu_{\text {Pmt Biasa }} \quad(\mathrm{y})=\left(\begin{array}{ll}
0 ; & \mathrm{y} \leq 25 \text { atau } \mathrm{y} \geq 35 \\
-25) / 5 ; & 25 \leq \mathrm{y} \leq 30 \\
(35-\mathrm{y}) / 5 ; & 30 \leq \mathrm{y} \leq 35
\end{array}\right.
\end{aligned}
$$


$\mu_{\text {Pmt Naik }} \quad(y)= \begin{cases}0 ; & y \leq 30 \\ -30) / 20 ; & 30 \leq y \leq 50 \\ 1 ; & y \geq 50\end{cases}$

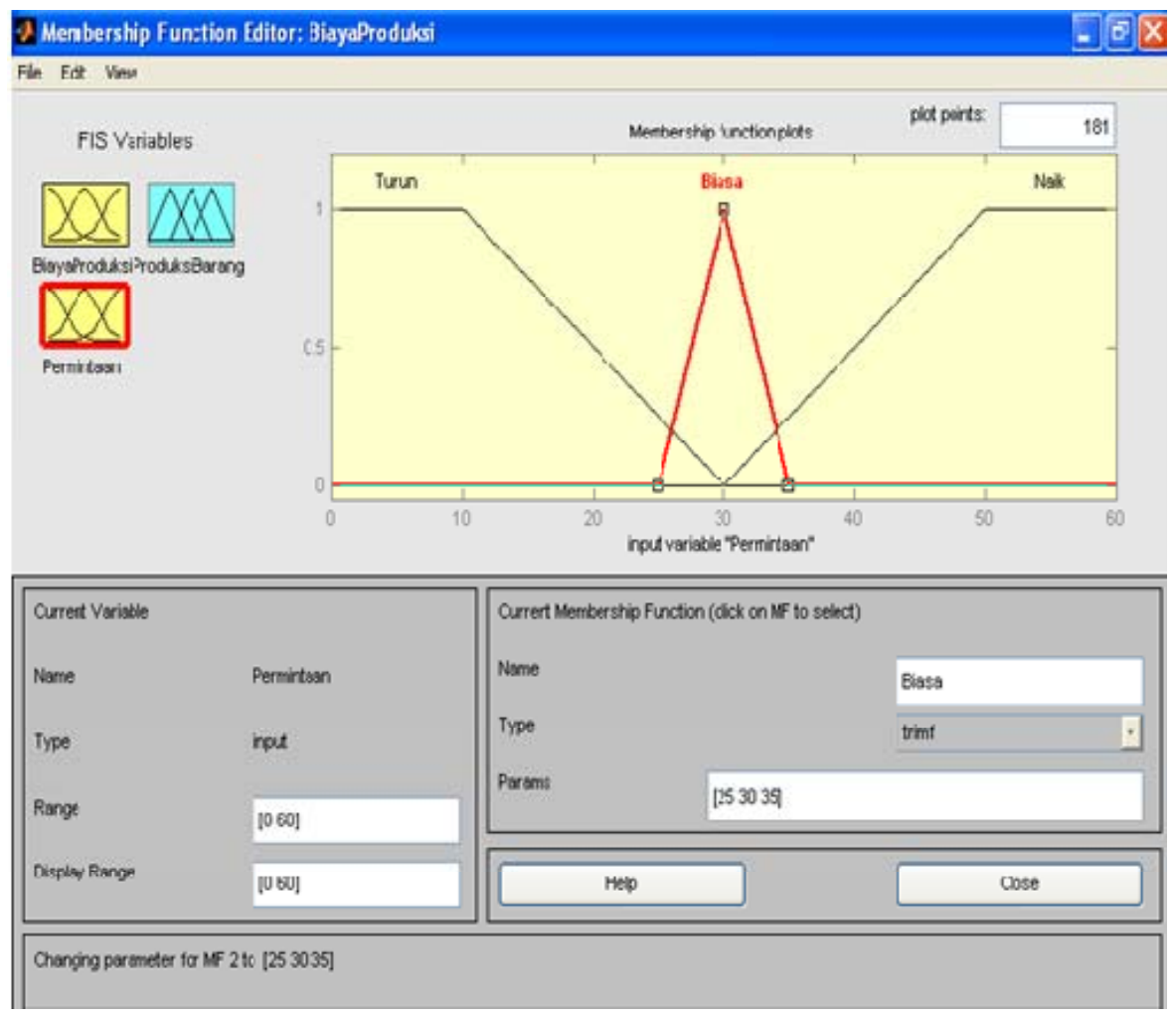

Gambar 9 Membership Function Editor: Permintaan

\section{Variabel Produksi Barang}

Untuk mempresentasikan variabel Produksi Barang digunakan kurva berbentuk bahu (untuk fuzzy BERKURANG \& BERTAMBAH) dan kurva bentuk segitiga (untuk himpunan fuzzy NORMAL) Gambar 10.

Fungsi KeanggotaanProduksi Barang:

$$
\begin{gathered}
\mu_{\text {PB Berkurang }}(\mathrm{z})=\left(\begin{array}{ll}
1 ; & \mathrm{z} \leq 10 \\
0-\mathrm{z})) / 40 ; & 10 \leq \mathrm{z} \leq 50 \\
0 ; & \mathrm{z} \geq 50
\end{array}\right. \\
\mu_{\text {PB Normal }}(\mathrm{y})= \begin{cases}0 ; & \mathrm{z} \leq 30 \text { atau } \mathrm{z} \geq 70 \\
\mathrm{z}-30) / 20 ; & 30 \leq \mathrm{z} \leq 50 \\
(70-\mathrm{z}) / 20 ; & 50 \leq \mathrm{z} \leq 70\end{cases} \\
\mu_{\text {PB Bertambah }}(\mathrm{y})=\left(\begin{array}{ll}
0 ; & \mathrm{z} \leq 50 \\
50) / 40 ; & 50 \leq \mathrm{z} \leq 90 \\
1 ; & \mathrm{z} \geq 90
\end{array}\right.
\end{gathered}
$$




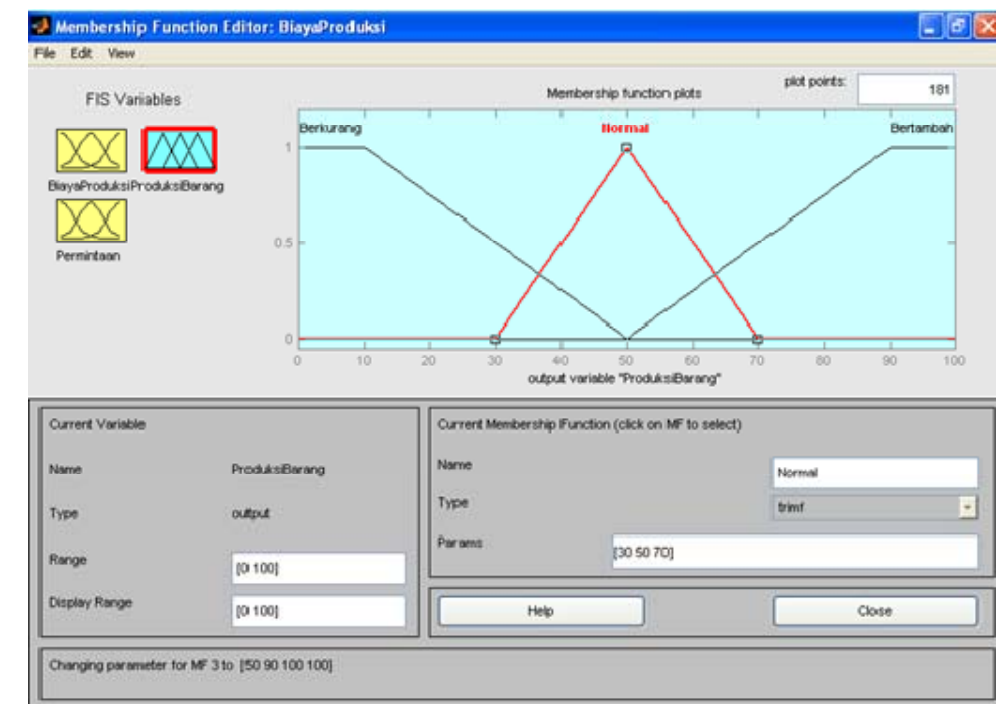

Gambar 10 Member Function Editor:Produksi Barang

\section{Aplikasi Operator Fuzzy}

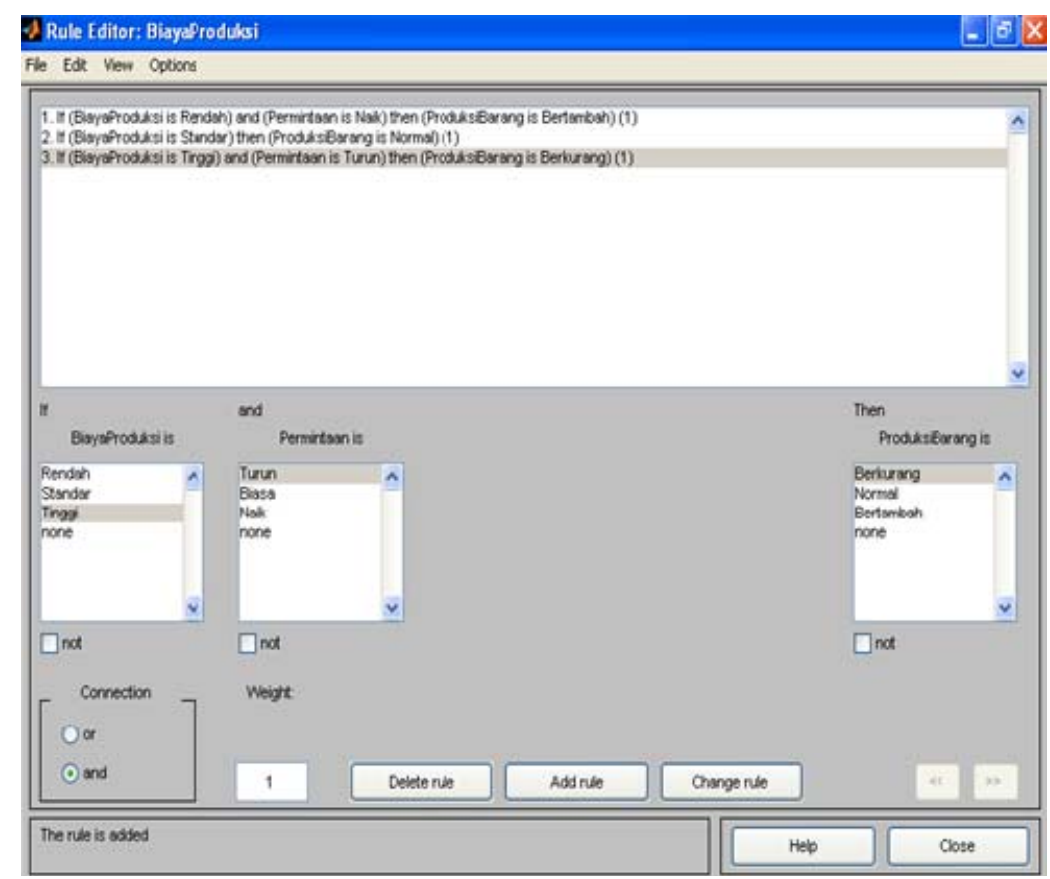

Gambar 11 Rule Editor

HASIL DAN PEMBAHASAN

\section{Aplikasi Fungsi Implikasi, Komposisi Semua Keluaran dan Defuzifikasi}

Hasil pengaplikasian dan komposisi semua keluaran dan defuzifikasi dapat dilihat dari Gambar 12 di bawah ini: 


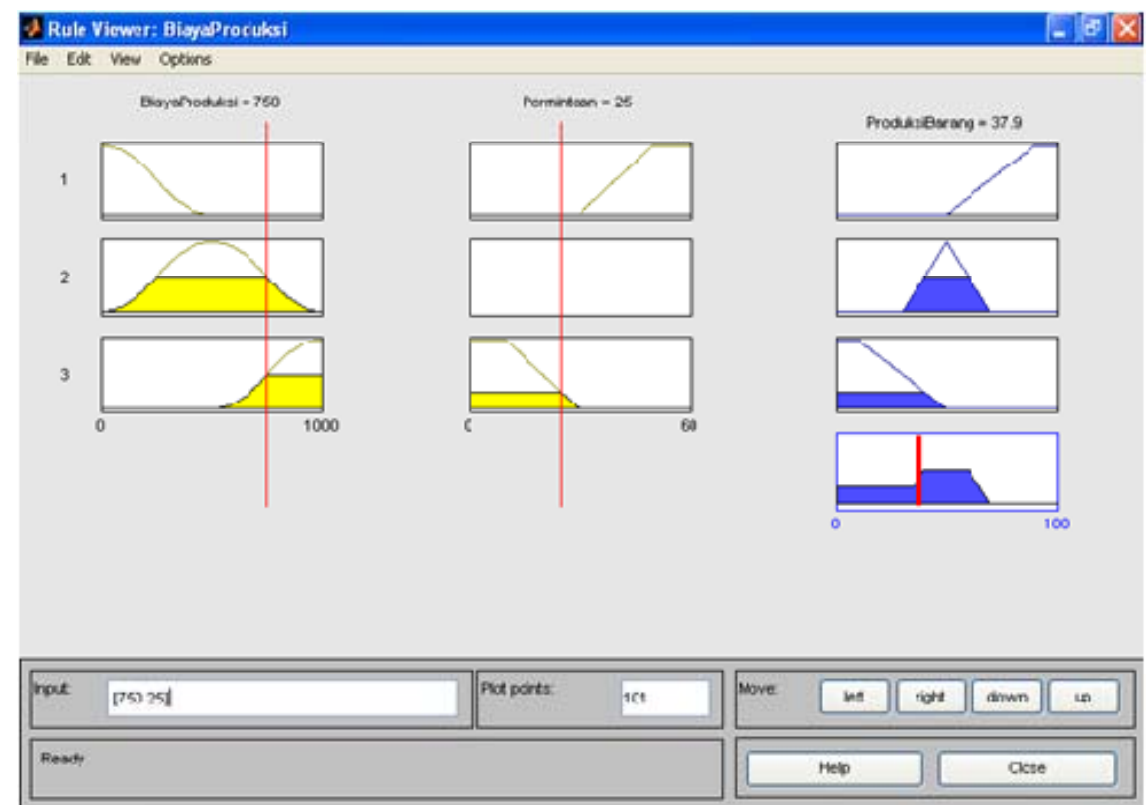

Gambar 12 Aplikasi Fungsi Implikasi, Komposisi Semua Keluaran dan Defuzifikasi

Defuzifikasi dilakukan dengan menggunakan metode centroid pada gambar di atas diperoleh hasil bahwa jika biaya memproduksi permen coklat jenis X diperkirakan sejumlah Rp.750 per kemasan dan permintaan mencapai 25.000 kemasan per hari maka jumlah permen coklat yang harus diproduksi 37.900 kemasan. Untuk melihat kaitan ketiga variabel dalam bentuk surface dapat dilihat pada Gambar 13 di bawah ini:

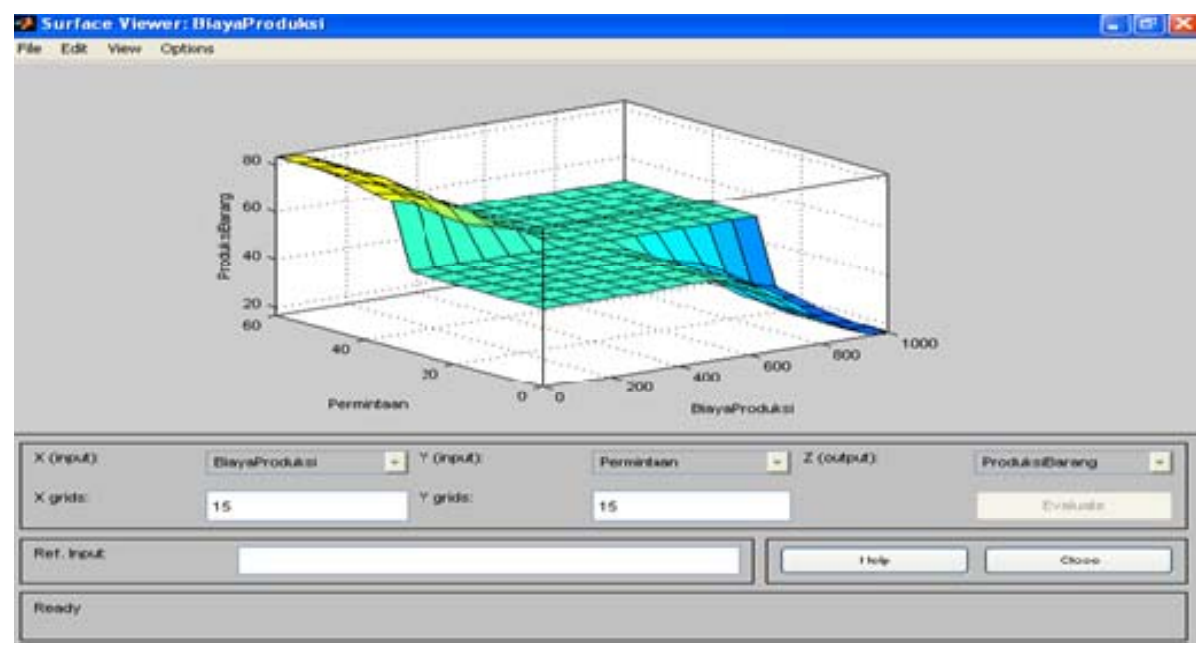

Gambar 13 Surface Viewer

\section{SIMPULAN}

Dari hasil pembuatan sistem fuzzy dengan menggunakan Toolbox Matlab Ver 7.0 dalam studi kasus di atas, terdapat beberapa tahapan proses pembentukan sistem fuzzy yaitu analisa input maupun 
output, penentuan variabel input dan output, penentuan fungsi keanggotaan masing-masing himpunan fuzzynya, penetapan aturan-aturan (rules) berdasarkan pengalaman atau pengetahuan seorang pakar dibidangnya dan implementasi sistem fuzzy.

Secara keseluruhan konsep logika fuzzy menggunakan konsep matematis sangat sederhana, mudah dimengerti dan memiliki toleransi terhadap data-data yang tidak tepat atau kabur. sistem fuzzy dapat membangun dan mengaplikasikan pengalaman-pengalaman para pakar secara langsung tanpa harus melalui proses latihan dan berusaha menerjemahkan pengetahuan yang dimiliki sang ahli ke dalam sistem komputer hingga menjadi suatu sistem pemodelan yang benar-benar bisa diandalkan dalam pengambilan keputusan.

\section{DAFTAR PUSTAKA}

Kusumadewi, S. (2002). Analisis dan Desain Sistem Fuzzy Menggunakan Tool Box MATLAB. Jakarta: Penerbit Graha Ilmu.

Kusumadewi, S., \& Purnomo, H. (2004). Aplikasi Logika Fuzzy untuk Mendukung Keputusan. Yogyakarta: Graha Ilmu.

Marimin. (2005). Teori dan aplikasi sistem pakar dalam tehnologi manajerial. Bogor: IPB Press. 